\title{
溶融 Al-Si-Mg 合金めっき鋼板のめっき組成と腐食挙動
}

\author{
山口 伸一 ${ }^{1) *}$. 真木 純 $^{1)} \cdot$ 黑㠃 将夫 ${ }^{1)}$ ・伊崎 輝明 2$)$ \\ Composition and Corrosion Behavior of Hot-dip Al-Si-Mg Alloy Coated Steel Sheets \\ Shinichi Yamaguchi, Jun Maki, Masao Kurosaki and Teruaki Izaki
}

Synopsis : This study was intended to investigate the effect of the amount of $\mathrm{Mg}$ and $\mathrm{Si}$ addition in the Al-Si coating in order to improve corrosion resistance of Aluminized steel sheets.

A salt spray test using formed specimens proved that Al-8mass\%Si-6mass $\%$ Mg-coated steel sheet having less cracks in the alloy layer after forming has the best corrosion resistance.

This outdoor exposure test using unformed specimens for 10 years proved that corrosion weight loss of Al-8mass $\% \mathrm{Si}-6 \mathrm{mass} \% \mathrm{Mg}$-coated steel sheet was reduced to approximately $30 \%$ less than that of Aluminized steel sheets and approximately $70 \%$ less than that of $55 \%$ aluminumzinc alloy-coated steel sheets; thereby, it was possible to confirm that Al-8mass\%Si-6mass\%Mg-coated steel sheet has favorable corrosion resistance under a long-term atmospheric environment.

This is supported to be the protective effects caused by corrosion products mixed with $\mathrm{Si}$ and $\mathrm{Mg}$, since the current value of the cathode polarization method of the specimen of Al- $8 \mathrm{mass} \% \mathrm{Si}-6 \mathrm{mass} \% \mathrm{Mg}$-coated steel sheet after the outdoor exposure test in an artificial rain solution were reduced by approximately $40 \%$ less than that of aluminized steel sheet.

Key words : Aluminized steel sheet; corrosion; outdoor exposure; $\mathrm{Mg}$; $\mathrm{Si}$.

\section{1. 諸言}

溶融アルミニウムめっき鋼板（以下，A1めっき鋼板）は， 溶融亜鉛めっき鋼板と比較して耐食性が優れ, 表面外観 の意匠性 (銀白色) に富んでいることから, 塗装無しで長 期間使用可能な表面処理鋼板として，自動車排気系材料を 始め, 屋根壁等の建材, 各種熱器具材, 自動車燃料タンク 材 $^{1)}$, 更に最近ではホットスタンプ工法を用いた超高強度 自動車部材 2 等への適用が広まりつつある。

$\mathrm{Al}$ の融点は約 $660^{\circ} \mathrm{C}$ と $\mathrm{Zn}$ に比べて高いために, 溶融めつ き時にめっき層と鋼板の界面に生成する金属間化合物の層 （通常，合金層と称される）が厚く成長して, 加工時にここ を起点としためっき剥離などが起きやすい。このためめつ き浴にSiを 8〜 10mass\%添加して合金層の成長を抑制した Type I という製品があり, 加工性と耐熱性に優れる。一方, 純Alめっき浴の Type II も存在し, 加工性は劣るもの耐食 性に優れるとされている ${ }^{3,4)}$ 。

めっきの主成分である $\mathrm{Al}$ は, 本来熱力学的に活性な金 属であるが, 大気環境下では表面に約 $1 \mathrm{~nm}$ の自然酸化皮膜 が形成され，この不動態皮膜により実用上は安定した耐食 性を示す5)。ただし，めっきが鋼に対して貴な電位を示す
ため, 大気暴露早期に加工部や切断端面部で鋼の腐食に伴 う赤錆が発生し易い。逆に, $\mathrm{Cl}^{-}$が $1.8 \mathrm{mass} \%$ の高濃度に存 在すると鋼より卑な電位を示す6) ため, めっきの犠牲防食 作用が発現することになる。大気環境下でこのようにめつ きの犠牲防食作用が発現する環境になる場合は, 塩害地域 等に限られるので, 鋼中に $11 \mathrm{mass} \% \mathrm{Cr}$ を添加して鋼の電 位を $\mathrm{Al} よ り$ 貴にすることで塩害地域以外の環境でも犠牲 防錆を発現させる方法が提案され実用化されている。この 材料は, 長期暴露後でも切断端面での鋼の腐食は認められ ず，平面部および剪断端面部ともに優れた耐食性を示し ている7,8)。ただし，11mass\%のCr添加鋼は高価なので，そ れ以外の方法として，めっき中に $\mathrm{Mg}$ を添加することで犠 牲防食作用を発現させる方法が提案されている。Enokida らは, $\mathrm{Al}$ と $\mathrm{Mg}_{2} \mathrm{Si}$ の擬二元共晶組成である $\mathrm{Al}-4.7 \mathrm{mass} \% \mathrm{Si}-$ $8.2 \mathrm{mass} \% \mathrm{Mg}$ で優れた犠牲防食性を示したと報告してい る9)。これにより大気暴露早期での加工部や剪断端面部か らの赤錆抑制が期待できるものの平面部でのめつき腐食量 増大や, 塩害環境下で加工によってめっきが多数損傷を受 けた部位での犠牲溶解によるめっき腐食量増大が懸念され る。

著者らは, 耐食性向上を目的として $\mathrm{Mg}$ を $\mathrm{Al}$ めっに添

平成 25 年3月7日受付 平成 25 年 5 月27日受理 (Received on Mar. 7, 2013 ; Accepted on May 27, 2013)

1）新日鐵住金 (株) 八幡技術研究部 (Yawata R\&D Lab., Nippon Steel \& Sumitomo Metal Corp., 1-1 Tobihatacho Tobata-Ku Kitakyushu-City 804-8501)

2）新日鐵住金 (株) 八幡技術研究部 (現：人事・労政部) (Yawata R\&D Lab., now Personnel \& Labor Relations Div. Nippon Steel \& Sumitomo Metal Corp.)

* Corresponding author : E-mail : yamaguchi.7rq.shinichi@jp.nssmc.com

DOI : http://dx.doi.org/10.2355/tetsutohagane.99.617 
加する技術を検討し，塩害環境下を想定した塩水噴霧試験 法により加工後の耐食性に優れためっき組成を導き出し

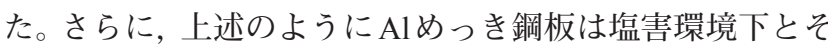
れ以外の環境下では異なる腐食挙動を示すため, 実機ライ ンにて試作した $\mathrm{Mg}$ 添加 $\mathrm{Al}$ めっき鋼板（以下， Al-Si-Mg 系 めっき鋼板と示す。）の10年間暴露試験を実施した結果， 大気環境下での耐食性についても明らかになったので報告 する。

\section{2. 実験方法}

\section{$2 \cdot 1$ 供試材}

評価に供した $\mathrm{Al}-\mathrm{Si}-\mathrm{Mg}$ 系めっき鋼板は，連続式溶融めっ きラインの熱履歴および䨌囲気を再現可能な縦型溶融めつ き装置を用いて作製した。原板には板厚 $0.8 \mathrm{~mm}$ の極低炭 素鋼を用いた。原板を $10 \mathrm{vol} \%$ の $\mathrm{H}_{2}$ を含む $\mathrm{N}_{2}$ 䨌囲気にて $800^{\circ} \mathrm{C}$ まで昇温して 60 秒間保持し， $\mathrm{N}_{2}$ にて浴温度まで冷却 後，めっき浴に 3 秒間浸漬してめっきした。浴温度は，各 組成の凝固温度 $+60^{\circ} \mathrm{C}$ に設定し，めっき付着量はガスワイ ピング法により片面当たり約 $40 \mathrm{~g} / \mathrm{m}^{2}$ に制御し，約 $10^{\circ} \mathrm{C} /$ 秒 で冷却した。めっき浴組成は, Fig.1のAl-Si-Mg系三元状 態図 ${ }^{10)}$ に印 $(\mathrm{A} \sim \mathrm{E})$ を付けた5 組成で，(A) Mgが添加さ れていない $\mathrm{Al}-\mathrm{Si}$ 系組成 (凝固温度 $598^{\circ} \mathrm{C}$ ) [Al-10mass $\% \mathrm{Si}$ ] (以下，表示が無い限り元素前の数值は mass \% を示す。)， (B) $\mathrm{Al}_{3} \mathrm{Mg}_{2}$ が初晶で凝固温度が最も低い $\left(580^{\circ} \mathrm{C}\right)$ 組成 $[\mathrm{Al}$ $2 \% \mathrm{Si}-12.4 \% \mathrm{Mg}] ，(\mathrm{C}) \mathrm{Al}-\mathrm{Mg}_{2} \mathrm{Si}$ 擬 2 元系で凝固温度が最も 低い $\left(593^{\circ} \mathrm{C}\right)$ 組成 $[\mathrm{Al}-4.7 \% \mathrm{Si}-8.2 \% \mathrm{Mg}] ，(\mathrm{D}) \mathrm{Mg}_{2} \mathrm{Si}$ が初晶 で (A) と同じ凝固温度 $\left(580^{\circ} \mathrm{C}\right)$ の組成 $[\mathrm{Al}-8 \% \mathrm{Si}-6 \% \mathrm{Mg}]$, (E) 三元共晶点で凝固温度が最も低い $\left(550^{\circ} \mathrm{C}\right)$ 組成 $[\mathrm{Al}$ $14.7 \% \mathrm{Si}-4.3 \% \mathrm{Mg}$ 〕を選択した。今回はめっき層と鋼との反 応により生成する合金層の成長抑制を考慮して，初晶が異 なる各組成域の中で凝固温度が最も低い組成を選択した。

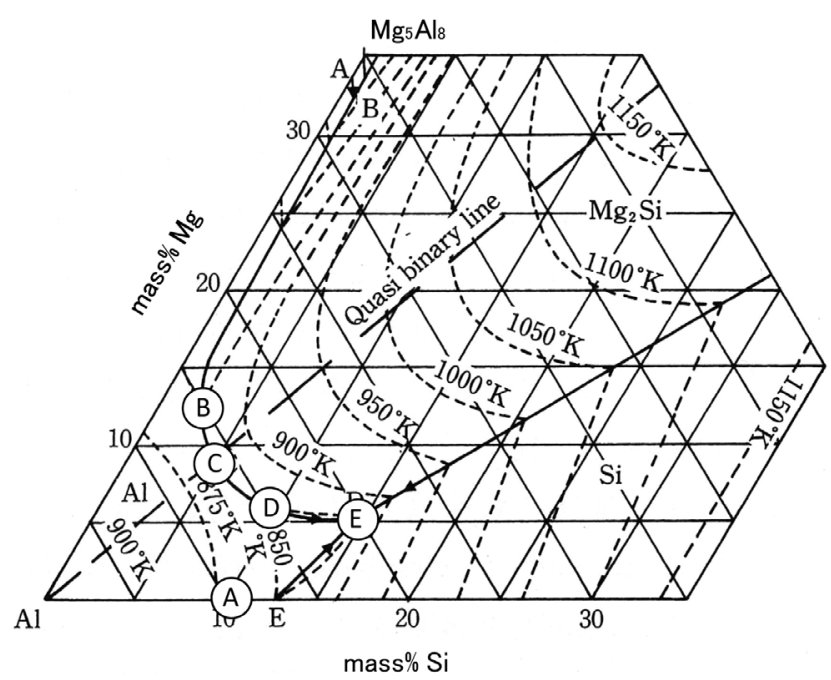

Fig. 1. Ternary Phase Diagram of Al-Si-Mg system.
各めっき浴中の $\mathrm{Fe}$ 濃度を飽和させるために $\mathrm{Al}-20 \% \mathrm{Fe}$ イン ゴットにて Fe濃度を $2 \%$ に調整した。暴露試験には連続式 溶融めっきライン $(\mathrm{CGL})$ で製造した $\mathrm{Al}-10 \% \mathrm{Si}$ めっき鋼 板 (以下, ALと示す。めっき付着量 ; 約 $42 \mathrm{~g} / \mathrm{m}^{2}$ ), $55 \% \mathrm{Al}$ $\mathrm{Zn}-1.2 \% \mathrm{Si}$ めっき鋼板 (以下, AZと示す。めっき付着量 ; 約 $75 \mathrm{~g} / \mathrm{m}^{2}$ ), $\mathrm{Al}-8 \% \mathrm{Si}-6 \% \mathrm{Mg}$ めっき鋼板 (めっき付着量; 約 $\left.40 \mathrm{~g} / \mathrm{m}^{2}\right)$ を供した。各材料ともにめっきままの状態で暴露 し，表面にクロメート処理等の化成処理は施していない。

\section{$2 \cdot 2$ 評価条件}

めっき層の断面は光学顕微鏡にて観察し，その構造は $\mathrm{Cu}$ をターゲットとしたX線回折装置 (XRD：リガク製 型 番RINT1500）にて分析した。めっきの耐食性の評価は，平 板の試験片とともに, Fig.2に示すドロービード金型（丸 型ビード：凸R4mm 一肩R2mm 材質：SKD11）間を押え 荷重 $1000 \mathrm{~kg}$ 一引抜速度 $200 \mathrm{~mm} / \mathrm{min}$ で引抜加工した試験片 を用いた。試験片に塗装は施さず，試験片の切断端面部 と董面をポリエステルテープにて被覆して塩水噴霧試験 （JIS-Z2371）に供した。

鋼が露出した箇所の防食メカニズムを調査するために, めっき面の一部で鋼を露出させた試験片にて浸漬腐食試験 を行った。平板の試験片 $(30 \mathrm{~mm} \times 50 \mathrm{~mm} \times 0.8 \mathrm{~mm})$ で鋼を 露出させる箇所 $(15 \mathrm{~mm} \times 15 \mathrm{~mm})$ 以外の部分をポリエステ ルテープにて保護して，めっき層を $0.5 \% \mathrm{AlCl}_{3}$ 水溶液中で の陽極電解および合金層を塩酸中で溶解させて部分的に鋼 を露出させた。 $25^{\circ} \mathrm{C}$ の $5 \% \mathrm{NaCl}$ (大気解放) 水溶液中に剪断 端面を蜜蝉にて保護した試験片を浸漬させ，72 時間後に取 り出して水洗, 乾燥させた。外観観察後に鋼露出部表面の X 線光電子分光分析 (XPS : PERKIN ELMER 製 PHI5500型) を行った。

大気暴露試験は，平板の試験片 $(70 \mathrm{~mm} \times 150 \mathrm{~mm} \times$ $0.8 \mathrm{~mm}$; 切断端面は全て上バリ) を北九州市の臨海工業地 域にて南向きで水平面に対して $30^{\circ}$ 傾斜した架台に取り付 けた。大気暴露環境は，八幡製鐵所構内，海岸より300〜 $500 \mathrm{~m}$ ，飛来塩分量は $0.15 \mathrm{mg} / \mathrm{dm}^{2} /$ day（1997測定）である。

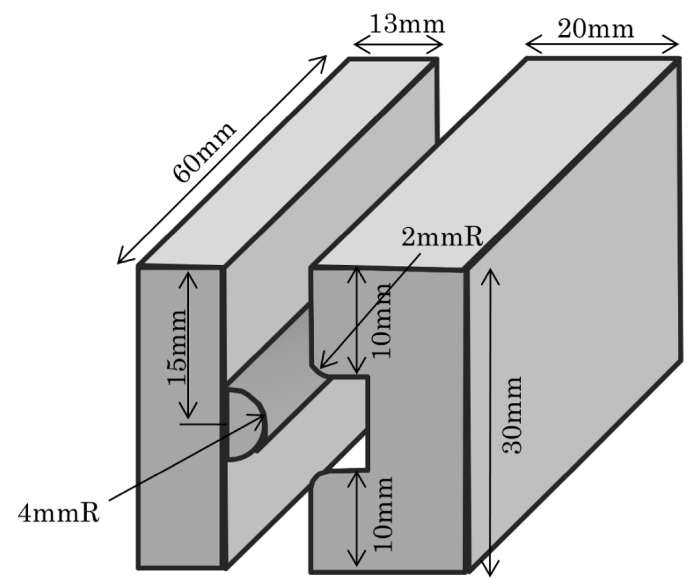

Fig. 2. Schematic diagram of Draw-bead-dies. 
試験後に試験片表面の腐食生成物を JIS Z2383 付属書Aに 準じた液に浸漬して除去後，重量測定し，試験前の重量と の差により腐食量を算出した。腐食生成物の元素分析は, 電子線マイクロアナライザー（EPMA：日本電子製JXA$8530 \mathrm{~F})$ およびグロー放電分光分析 (GDS：堀場製作所製 GD-Profiler2)にて行った。

電気化学測定は, $5 \% \mathrm{NaCl}$ 水溶液および模擬雨水 $\left(\mathrm{Cl}^{-}\right.$ $\left.200 \mathrm{ppm}, \mathrm{SO}_{4}{ }^{2-} 200 \mathrm{ppm}\right)^{6)}$ 用い $25^{\circ} \mathrm{C}$, 大気開放の条件下 で行った。測定はSolortron製のポテンショ/ガルバノス タットと周波数応答アナライザ（FRA）を組合せた電気化 学測定システムで直流分極打よび交流インピーダンス法 にて行った。直流分極法では, $15 \mathrm{~mm} \times 60 \mathrm{~mm}$ に切り出し 後, $1.08 \mathrm{~cm} \phi$ の領域（面積 $1 \mathrm{~cm}^{2}$ ) を除いた部位をテープ シールして測定に供した。めっき鋼板を試験液に浸漬し， 1 分後の電位を浸漬電位としてこの電位よりカソード側に $1 \mathrm{mV} / \mathrm{sec}$ で插引した。

交流インピーダンス測定では，上述条件で平板およびド ロービード加工した材料を $15 \mathrm{~mm} \times 60 \mathrm{~mm}$ で切り出し後, $1.08 \mathrm{~cm} \phi$ の領域 (面積 $1 \mathrm{~cm}^{2}$ ) を除いた部位をテープシール して測定に供した。めっき鋼板を試験液に浸漬し約 1 分後 に浸漬電位を求め, その電位に電極電位を固定した状態で $30 \mathrm{mV}$ の交流電圧を印加し，周波数範囲 $65000 \sim 1 \mathrm{~Hz}$ で走查 して行った。得られたCole-Cole プロットから反応抵抗を 求めた。

\section{3. 結果および考察}

\section{3・1 めっき組織}

Fig.3に各組成でのめっき断面組織を, Fig.4, Table 1 に めっき層の $\mathrm{X}$ 線回折分析結果と合金層厚み測定の結果を示 す。合金層の厚みは，任意の箇所 10 点の合金層厚みの平均 值 (小数第一位を四捨五入) とした。ただし, $\mathrm{Al}-14.7 \% \mathrm{Si}$ $4.3 \% \mathrm{Mg}$ めっに認められる粗大な棒状の合金は除いて測 定した。

$\mathrm{Al}-10 \% \mathrm{Si}$ めっきでは, 針状の $\mathrm{Si}$ 晶とともに $\mathrm{Al}-\mathrm{Fe}-\mathrm{Si}$ 合金 層が認められた。針状の $\mathrm{Si}$ 晶は，めっき表面から合金層ま でめっきを貫くように晶出しているものも認められた。

$\mathrm{Al}-2 \% \mathrm{Si}-12.7 \% \mathrm{Mg}$ めっきの合金層は, 凹凸が激しく, か つ $8 \mu \mathrm{m}$ と厚く成長している箇所が認められた。合金層が厚 く成長したのは, Type II と同様にめっき浴中 Si濃度が低い ことが推定される。 $\mathrm{Al}$ や $\mathrm{Mg}_{2} \mathrm{Si}$ に帰属するピークが検出さ れた。状態図からは $\mathrm{Mg}_{5} \mathrm{Al}_{8}$ も晶出する領域であるが, X線 回折分析では検出されなかった。A1相部を EPMA点分析 すると $\mathrm{Mg}$ が約 $13 \%$ 検出され, $\mathrm{Al}$ 側の $\mathrm{Mg}$ の最大固溶度は $18.6 \%\left(450^{\circ} \mathrm{C}\right.$ 時) である ${ }^{11)}$ ことから, $\mathrm{Mg}$ は $\mathrm{Al}$ 相中に固溶 しているものと推定される。

$\mathrm{Al}-\mathrm{Mg}_{2} \mathrm{Si}$ 擬 2 元共晶組成である $\mathrm{Al}-4.7 \% \mathrm{Si}-8.2 \% \mathrm{Mg}$ めつ き層でも，6 $\mu \mathrm{m}$ の厚い合金層が成長していた。理由は $\mathrm{Al}-$
$2 \% \mathrm{Si}-12.7 \% \mathrm{Mg}$ めっきと同様に, めっき浴中 $\mathrm{Si}$ 濃度が低い ことと, 浴温度が $653^{\circ} \mathrm{C}$ と今回の条件の中では最も高かっ たことが影響していると考えられる。めっき組織は $\mathrm{Al}$ 層中 に微細な $\mathrm{Mg}_{2} \mathrm{Si}$ 晶が認められ, $\mathrm{Al}-\mathrm{Mg}_{2} \mathrm{Si}$ 擬2 元共晶組織で あった。

$\mathrm{Al}-8 \% \mathrm{Si}-6 \% \mathrm{Mg}$ めっきの合金層の厚みは，上記 2 組成 めっきとは異なり, $3 \mu \mathrm{m}$ と今回調査しためっきの中で最も 薄かった。めっき表面や合金層近傍に塊状 $\mathrm{Mg}_{2} \mathrm{Si}$ が認めら れ，それ以外は $\mathrm{Al}$ 晶と $\mathrm{Al}-\mathrm{Mg}_{2} \mathrm{Si}$ 共晶組織が認められた。

$\mathrm{Al}-14.7 \% \mathrm{Si}-4.3 \% \mathrm{Mg}$ めっの合金層の厚みは, $4 \mu \mathrm{m}$ で あった。浴温度が $610^{\circ} \mathrm{C}$ と今回の条件の中では, 最も低い にも関わらず $\mathrm{Al}-8 \% \mathrm{Si}-6 \% \mathrm{Mg}$ めっきり合金層が増加した 理由については, 針状の粗大な合金層も生成していること から合金層の組成が変化したことが影響したと推察され る。また, 状態図からめっき層は, $\mathrm{Al}-\mathrm{Mg}_{2} \mathrm{Si}-\mathrm{Si}$ の三元共晶 組織が晶出する組成であるものの, $\mathrm{Al}-\mathrm{Mg}_{2} \mathrm{Si}$ の二元共晶組

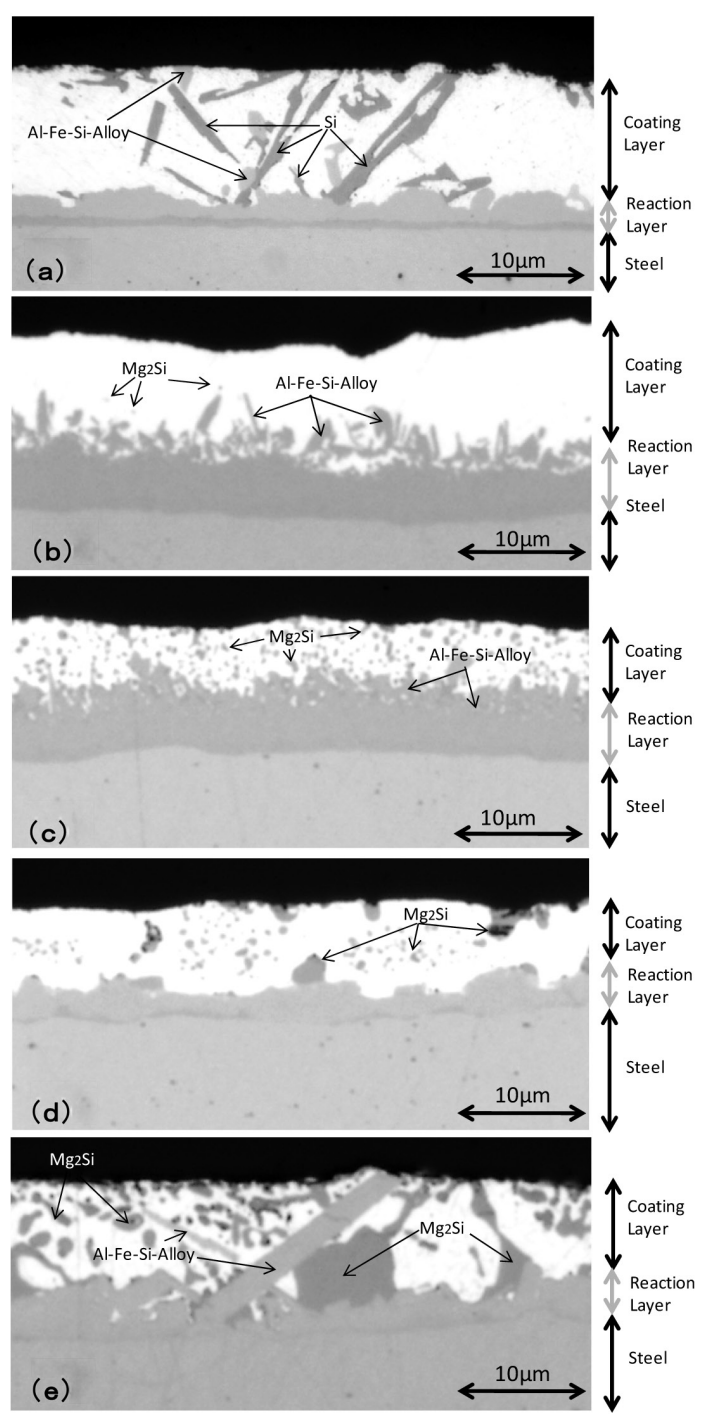

Fig. 3. Cross-sectional structures of each specimen (a) Al$10 \% \mathrm{Si}$, (b) $\mathrm{Al}-2 \% \mathrm{Si}-12.7 \% \mathrm{Mg}$, (c) $\mathrm{Al}-4.7 \% \mathrm{Si}-8.2 \% \mathrm{Mg}$, (d) $\mathrm{Al}-8 \% \mathrm{Si}-6 \% \mathrm{Mg}$, (e) $\mathrm{Al}-14.7 \% \mathrm{Si}-4.3 \% \mathrm{Mg}$. 
織が大部分を占めていた。鋼板界面での合金層の生成によ る $\mathrm{Si}$ の消費により凝固時のめっき組織が低 $\mathrm{Si}$ 組成側の $\mathrm{Al}$ 初晶領域組成に変化していたためと推定される。

以上のように, めっき層組織は, $\mathrm{Al}$ 中への $\mathrm{Mg}$ の固溶や 合金層の生成による $\mathrm{Si}$ の消費の影響が認められた。 $\mathrm{Al}-\mathrm{Si}-$ $\mathrm{Mg}$ 系めっきでは，めっき中を貫通する形態での連なっ た針状 Si晶はほとんど認められなかった。これは, Siが $\mathrm{Mg}_{2} \mathrm{Si}$ として晶出するためと推察される。また，合金層の 厚みは, $\mathrm{A} 1$ めっ鋼板と同様に $\mathrm{Si}$ 比率に依存し ${ }^{12,13)}, 8 \%$ の添加で3um まで低下した。

Table. 1. X-Ray Diffraction Identification results of each specimens. (a) Al-10\% Si, (b) Al-2\% $\mathrm{Si}-12.7 \% \mathrm{Mg}$, (c) $\mathrm{Al}-$ $4.7 \% \mathrm{Si}-8.2 \% \mathrm{Mg}$, (d) Al- $8 \% \mathrm{Si}-6 \% \mathrm{Mg}$, (e) Al- $14.7 \% \mathrm{Si}-$ $4.3 \% \mathrm{Mg}$.

\begin{tabular}{|c|c|c|c|c|c|}
\hline & (a) & (b) & (c) & (d) & (e) \\
\hline $\begin{array}{l}\text { Thichness of } \\
\text { alloy layer }(\mu \mathrm{m})\end{array}$ & 3 & 8 & 6 & 3 & 4 \\
\hline ๑ : $\mathrm{Al}$ & - & - & - & $\bullet$ & $\bullet$ \\
\hline$\diamond: \mathrm{Si}$ & $\bullet$ & & & & \\
\hline - $: \mathrm{Al}_{8} \mathrm{Fe}_{2} \mathrm{Si}$ & $\Delta$ & & $\Delta$ & $\Delta$ & $\Delta$ \\
\hline 站: $\mathrm{Mg}_{2} \mathrm{Si}$ & & is & $i$ & $\hbar$ & it \\
\hline
\end{tabular}

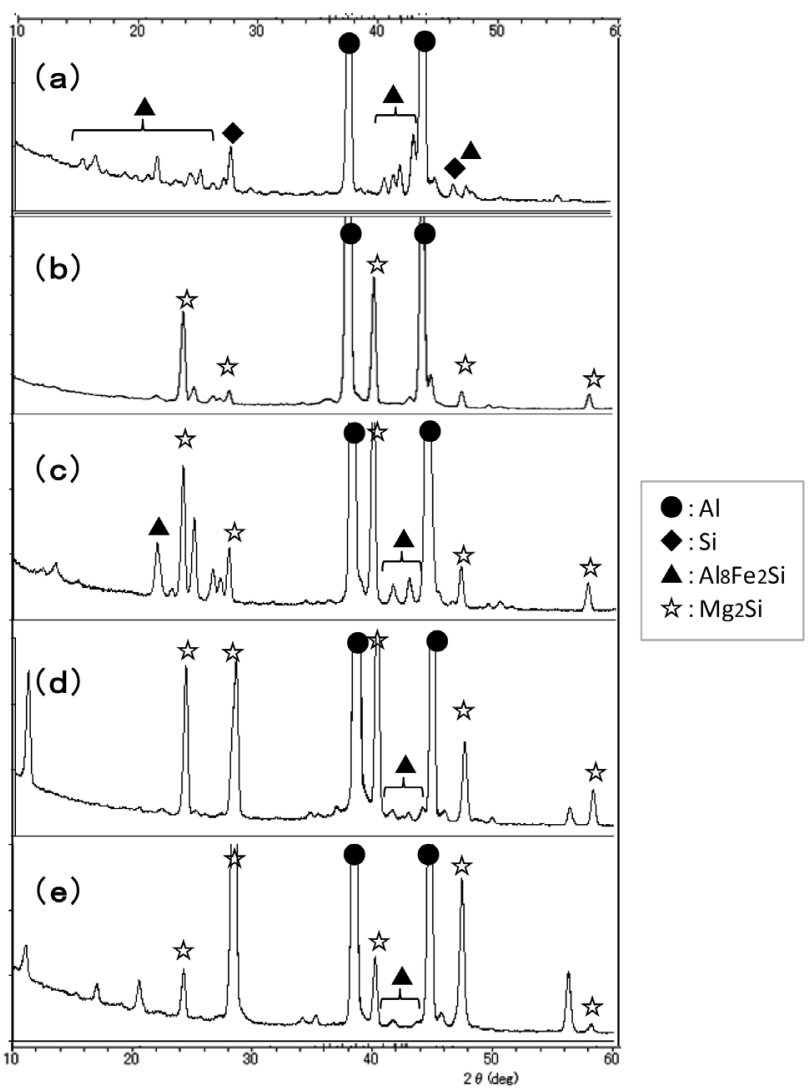

Fig. 4. X-ray diffraction patterns of each specimen. (a) Al$10 \% \mathrm{Si}$, (b) $\mathrm{Al}-2 \% \mathrm{Si}-12.7 \% \mathrm{Mg}$, (c) $\mathrm{Al}-4.7 \% \mathrm{Si}-8.2 \% \mathrm{Mg}$, (d) $\mathrm{Al}-8 \% \mathrm{Si}-6 \% \mathrm{Mg}$, (e) $\mathrm{Al}-14.7 \% \mathrm{Si}-4.3 \% \mathrm{Mg}$.

\section{$3 \cdot 2$ めっき耐食性}

Fig.5 に平板およびドロービード加工材の塩水噴霧試験 500 時間後のめっき腐食量を示す。平板の場合, $\mathrm{Al}-10 \% \mathrm{Si}$ めっき鋼板の腐食量が $15.8 \mathrm{~g} / \mathrm{m}^{2}$ であったのに比較して, $\mathrm{Mg}$ を添加した $\mathrm{Al}-2 \% \mathrm{Si}-12.7 \% \mathrm{Mg}$ めっき鋼板が $5.1 \mathrm{~g} / \mathrm{m}^{2}, \mathrm{Al}-$ $4.7 \% \mathrm{Si}-8.2 \% \mathrm{Mg}$ めつき鋼板が $7.1 \mathrm{~g} / \mathrm{m}^{2}, \mathrm{Al}-8 \% \mathrm{Si}-6 \% \mathrm{Mg}$ めつ き鋼板が $6.0 \mathrm{~g} / \mathrm{m}^{2}, \mathrm{Al}-14.7 \% \mathrm{Si}-4.3 \% \mathrm{Mg}$ めっき鋼板 $7.8 \mathrm{~g} / \mathrm{m}^{2}$ であった。今回の $\mathrm{Mg}$ 添加めっき組成間では腐食量に大き な差異は認められず, $\mathrm{Al}-10 \% \mathrm{Si}$ めっき鋼板に比較して $\mathrm{Mg}$ 添加することで約3分の 1 まで腐食量が減少した。

一方，ドロービード加工材の場合, $\mathrm{Al}-10 \% \mathrm{Si}$ めっ鋼板 の腐食量は, 加工前の 10 倍の $138 \mathrm{~g} / \mathrm{m}^{2}$ まで増加した。加工 により腐食量が増加した理由は, 加工時に発生するめっ き層や合金層のクラックによってめっき層より電位的に 貴である合金層 ${ }^{5)}$ や鋼が露出し，めっき層が犠牲防食的 に溶解したためと推察される。 $\mathrm{Mg}$ を添加しためっきで は, $\mathrm{Al}-2 \% \mathrm{Si}-12.7 \% \mathrm{Mg}$ めっき鋼板が $129.1 \mathrm{~g} / \mathrm{m}^{2}, \mathrm{Al}-4.7 \% \mathrm{Si}-$ $8.2 \% \mathrm{Mg}$ めっき鋼板が $21.8 \mathrm{~g} / \mathrm{m}^{2}, \mathrm{Al}-8 \% \mathrm{Si}-6 \% \mathrm{Mg}$ めっき鋼 板が $8.5 \mathrm{~g} / \mathrm{m}^{2}, \mathrm{Al}-14.7 \% \mathrm{Si}-4.3 \% \mathrm{Mg}$ めっき鋼板 $14.8 \mathrm{~g} / \mathrm{m}^{2}$ であ り, Mg添加めっき組成間でめっき腐食量に差異が生じ, Al-8\%Si-6\%Mgめっきでの腐食量が最も少なかった。Fig.6 にドロービード加工後の各種めっきの合金層クラック率を 示す。合金層クラック率は, 観察視野幅 $1.3 \mathrm{~mm}$ 中での合金 層が剥離して鋼が露出している長さの合計の比率を算出 したものである。合金層が厚く成長した $\mathrm{Al}-2 \% \mathrm{Si}-12.7 \% \mathrm{Mg}$ めっき鋼板や $\mathrm{Al}-4.7 \% \mathrm{Si}-8.2 \% \mathrm{Mg}$ めっ鋼板は, クラック 率が約 $40 \%$ と高く，最も合金層が薄い $\mathrm{Al}-8 \% \mathrm{Si}-6 \% \mathrm{Mg}$ めつ き鋼板のクラック率は $24 \%$ と最も低く, $\mathrm{Al}-10 \% \mathrm{Si}$ めっき鋼 板相当であった。以上のように, Mg添加めっき組成間で は加工材の合金層クラック率と腐食減量には相関があり, 合金層クラック率が低い $\mathrm{Al}-8 \% \mathrm{Si}-6 \% \mathrm{Mg}$ めっき鋼板が最も 優れた加工部耐食性を示した。

Mg添加により耐食性が向上した理由について明らかに

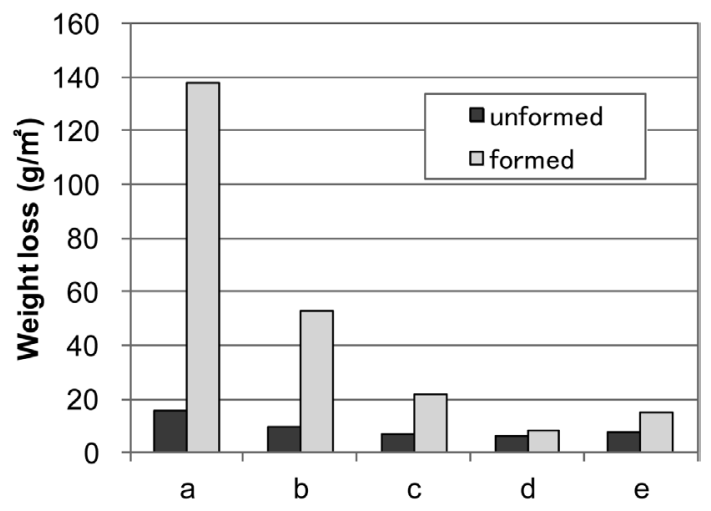

Fig. 5. Effect of alloying elements on corrosion after 500 hours of salt spray test (a) $\mathrm{Al}-10 \% \mathrm{Si}$, (b) $\mathrm{Al}-2 \% \mathrm{Si}-12.7 \% \mathrm{Mg}$, (c) $\mathrm{Al}-4.7 \% \mathrm{Si}-8.2 \% \mathrm{Mg}$, (d) Al- $8 \% \mathrm{Si}-6 \% \mathrm{Mg}$, (e) Al$14.7 \% \mathrm{Si}-4.3 \% \mathrm{Mg}$. 
するために, 鋼を露出させためっき鋼板の浸漬腐食試験 にて鋼露出部に生成した防錆皮膜を調查した。 $5 \% \mathrm{NaCl}$ 水 溶液中浸漬 72 時間後の $\mathrm{Al}-8 \% \mathrm{Si}-6 \% \mathrm{Mg}$ めっき鋼板と $\mathrm{Al}-$ $10 \% \mathrm{Si}$ めっき鋼板のサンプル外観を Fig.7に示す。 $\mathrm{Al}-10 \% \mathrm{Si}$ めっき鋼板ではでは鋼露出部分全面から赤錆が発生して いるのに対して, $\mathrm{Al}-8 \% \mathrm{Si}-6 \% \mathrm{Mg}$ めっき鋼板の鋼露出部は, 全く錆が認められず試験開始前と外観に大きな変化は認 められなかった。その鋼露出部分のXPS 分析結果を Fig.8 に示す。 $\mathrm{Al}, \mathrm{Si}, \mathrm{Mg}, \mathrm{O}$ を主成分とする 50〜 90nm厚みの皮 膜が鉄面を被覆しており，先の皮膜の元素濃度比は, $\mathrm{Mg}$ ： $\mathrm{Al}: \mathrm{Si}=17: 6: 4$ で Mg や Siを含有した $\mathrm{Al}$ 腐食生成物皮 膜が形成されていた。

次に, 上記 $\mathrm{Mg}$ や $\mathrm{Si}$ 含有した $\mathrm{Al}$ 腐食生成物皮膜の防錆 能について電気化学的にて検討した。Fig. 9 に $5 \mathrm{NaCl}$ 水溶 液中に打ける交流インピーダンス法から求めた反応抵抗 の経時変化を示す。 $\mathrm{Al}-10 \% \mathrm{Si}$ めっき鋼板および $\mathrm{Al}-8 \% \mathrm{Si}-$ $6 \% \mathrm{Mg}$ めっき鋼板の平板およびドロービード加工材を供試 材とした。平板の Al-10\%Siめっき鋼板に打いて浸漬初期で

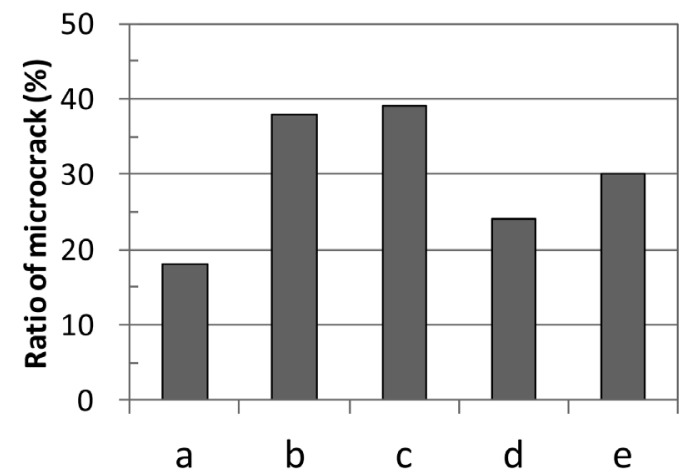

Fig. 6. Ratio of microcrack of Al-Si-Fe alloy layer after drawing test (a) Al-10\% $\mathrm{Si}$, (b) $\mathrm{Al}-2 \% \mathrm{Si}-12.7 \% \mathrm{Mg}$, (c) $\mathrm{Al}-4.7 \% \mathrm{Si}-$ $8.2 \% \mathrm{Mg}$, (d) Al-8\%Si-6\%Mg, (e) Al-14.7\% $\mathrm{Si}-4.3 \% \mathrm{Mg}$.

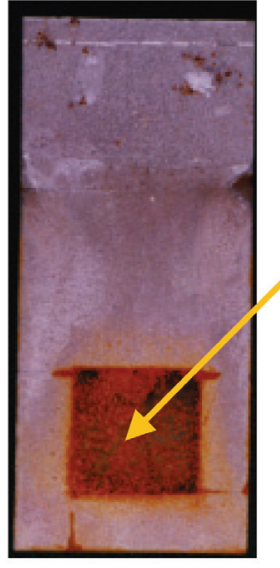

(a) $\mathrm{Al}-10 \% \mathrm{Si}$

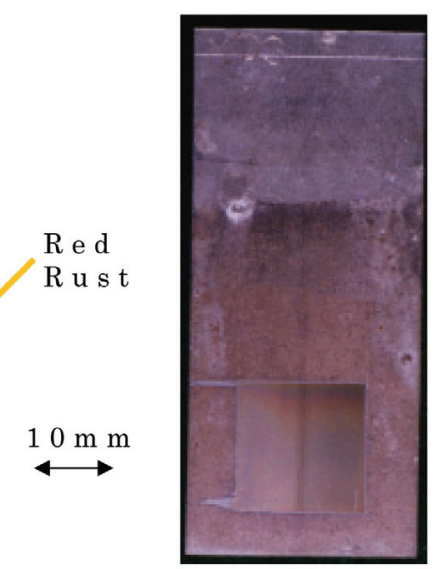

(b) $\mathrm{Al}-8 \% \mathrm{Si}-6 \% \mathrm{Mg}$
Fig. 7. The appearance of specimens removed a part of coating after immersion test in $5 \mathrm{mass} \% \mathrm{NaCl}$ at $25^{\circ} \mathrm{C}$ for 24 hours (a) Al-10\% $\mathrm{Si}$, (d) Al-8\% Si-6\%Mg. (Online version in color.)
の反応抵抗は $\mathrm{Al}$ 固有の不動態皮膜の影響で $1.2 \times 10^{5} \mathrm{ohm} \cdot$ $\mathrm{cm}^{2}$ と高い值を示した。Al-10\%Siめっき鋼板で加工を加え た場合は，露出した鋼部や合金層部がカソードとなり腐食 反応が促進されるため反応抵抗は $4 \times 10^{3} \mathrm{ohm} \cdot \mathrm{cm}^{2}$ まで低 下した。経時変化に着目すると当初高い反応抵抗を示した 平板の $\mathrm{Al}-10 \% \mathrm{Si}$ めっ鋼板も時間と伴に反応抵抗が減少 し，約 100 時間で加工材と同等の值となった。これは腐食 液中に含有される $\mathrm{Cl}^{-}$の影響でめっき表面に存在した不動 態皮膜が破壊され腐食反応が促進したためと考えられる。 加工材は経時とともに反応抵抗が微増した。これは, 腐食 生成物が表面を被覆したためと考えられる。

一方, 平板の $\mathrm{Al}-8 \% \mathrm{Si}-6 \% \mathrm{Mg}$ めっき鋼板では, 浸漬初期 は $2 \times 10^{4} \mathrm{ohm} \cdot \mathrm{cm}^{2}$ と低い反応抵抗を示した。これはめっ き層中に含有されている $\mathrm{Mg}_{2} \mathrm{Si}$ が活性溶解したためと考え られる。加工材の $\mathrm{Al}-8 \% \mathrm{Si}-6 \% \mathrm{Mg}$ めっ鋼板では，露出し た鋼部や合金層部がカソードとなり腐食反応が促進され るため, 浸漬初期は $2 \times 10^{3} \mathrm{ohm} \cdot \mathrm{cm}^{2}$ と更に低い反応抵抗

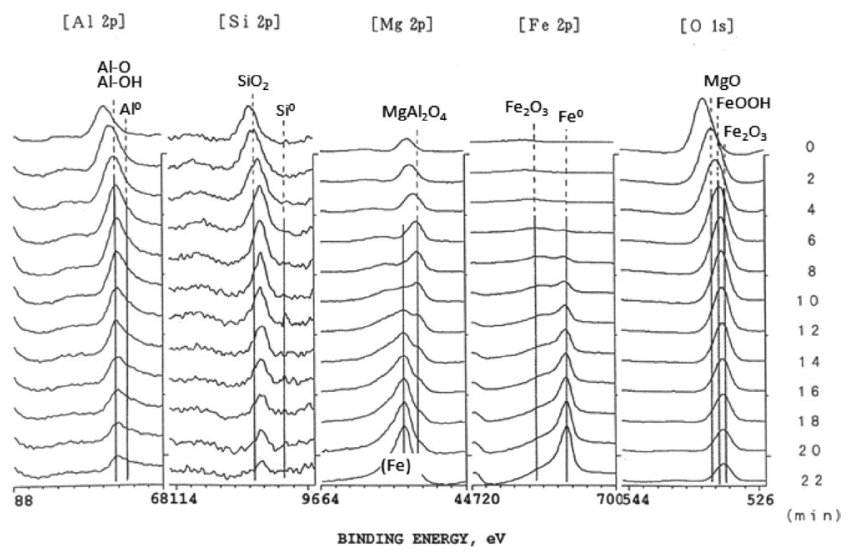

Fig. 8. XPS depth profile of the steel surface removed the part of Al-8\% $\mathrm{Si}-6 \% \mathrm{Mg}$ coating after immersion test for 24hours.

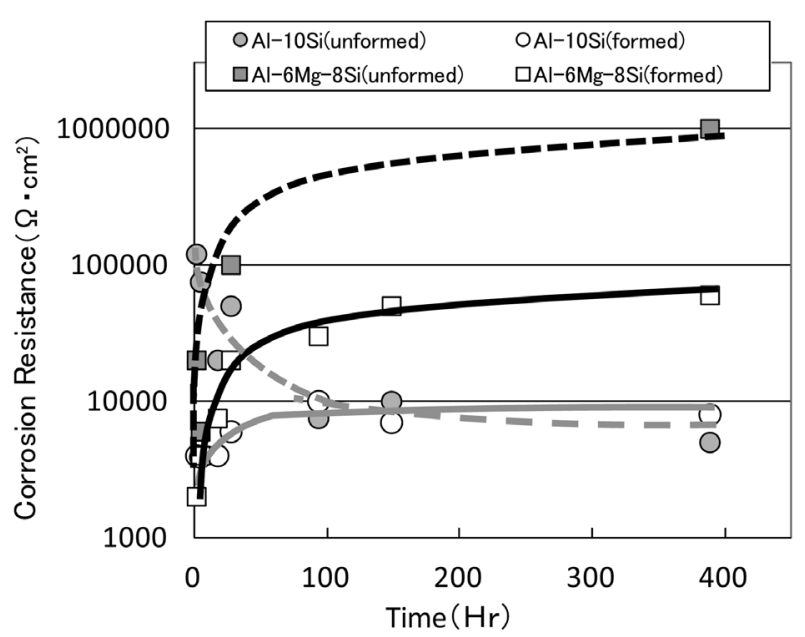

Fig. 9. Change of corrosion resistance by alternating current impedance method of each specimen in $5 \mathrm{mass} \% \mathrm{NaCl}$ at $25^{\circ} \mathrm{C}$. 


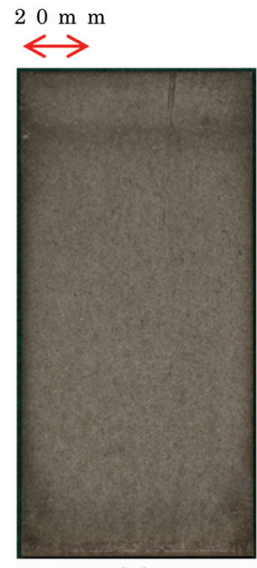

(A)

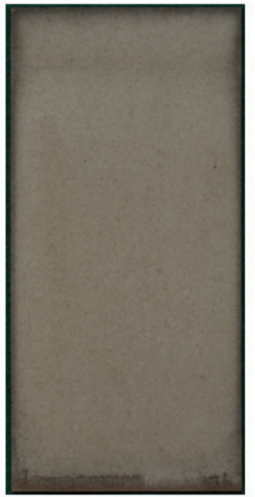

(B)

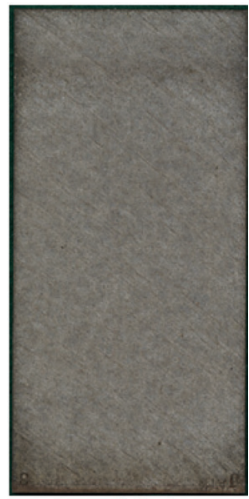

(C)

Fig. 10. The appearance of specimens exposed at Yawata for 10 years (A) AL (B) AZ (C) Al-8\% Si-6\%Mg. (Online version in color.)

を示した。ただし，平板および加工材共に，時間経過とと もに反応抵抗は上昇して 100 時間後までに平板の $\mathrm{Al}-10 \% \mathrm{Si}$ めっき鋼板より一桁高い值を示し，時間経過とともに更に 上昇した。これは，上記浸漬腐食試験で認められた $\mathrm{Mg} や$ $\mathrm{Si}$ 含有した $\mathrm{A} 1$ 腐食生成物がめっきや合金層などの表面 を覆うために腐食反応が抑制された結果と考えられる。

以上のように, $\mathrm{Al}$ めっ鋼板に $\mathrm{Mg}$ を添加することで耐 食性の向上が確認された。今回の Mgを添加しためっき組 成において, 平板での耐食性については組成間の差異はほ とんど認められなかったものの，加工材での耐食性では めっきと鋼の界面に生成する合金層の厚みが影響し, 合金 層の成長抑制により加工時のめっきや合金層のクラックが 少なかった $\mathrm{Al}-8 \% \mathrm{Si}-6 \% \mathrm{Mg}$ めっき鋼板が最も優れた加工後 耐食性を示した。Mg添加により腐食量が減少した理由と しては, Morimoto らの報告 ${ }^{14)}$ と同様に腐食生成物への Mg や $\mathrm{Si}$ の含有によるアノード反応であるめっき皮膜の溶解 反応，溶存酸素のカソード反応の両反応が抑制されたため と推定される。

\section{$3 \cdot 3$ 屋外暴露試験におけるめっきの腐食挙動}

Fig.10にAL，AZ，Al-8\%Si-6\%Mgめつき鋼板の 10 年屋 外暴露材外観を示す。ALのめっき表面に打いて全体的に 色調が低下し，切断端面部からの黒変が認められるのに対 して, Al-8\%Si-6\%Mgめっき鋼板の色調低下や切断端面部 からの黒変は抑制されていた。ALの色調低下や切断端面 部からの黒変については, $\mathrm{A} 1$ の腐食生成物に鋼の腐食生 成物が取り込まれたものであることが報告されており ${ }^{15)}$, $\mathrm{Mg}$ を添加することで屋外の大気環境でも鋼の腐食が抑制 されたことを示唆する外観であった。Fig.11にめっき腐食 量の経時変化を示す。 AZは，暴露 1 年後では $7.1 \mathrm{~g} / \mathrm{m}^{2}$ の腐 食量，その後は腐食量の傾きが緩やかになり，10年後では $20.4 \mathrm{~g} / \mathrm{m}^{2}$ の腐食量でWillisの結果 ${ }^{16)}$ とほぼ一致した。AL は, 初期過程では直線的に腐食量が増加するものの, 4 年

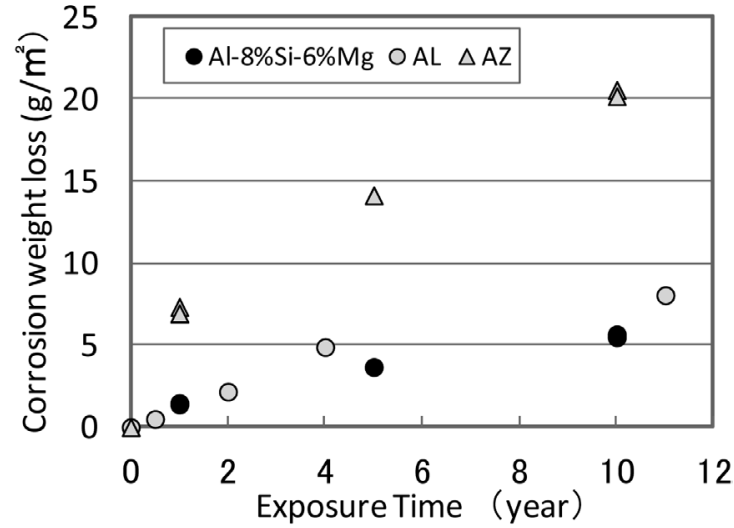

Fig. 11. Change of corrosion weight loss in the exposure.

目以降より腐食量が減少し, 11 年後で $8.1 \mathrm{~g} / \mathrm{m}^{2}$ の腐食量で あった。減少する理由については, $\mathrm{Al}$ イオンで鋼の腐食生 成物が緻密になり酸素等の腐食因子となる物質の拡散が抑 制されるためと報告されている。 $\mathrm{Al}-8 \% \mathrm{Si}-6 \% \mathrm{Mg}$ めっき鋼 板の腐食量は，腐食 1 年後は, ALとほぼ同レベルあった。 腐食初期過程ではめっき表面に露出している $\mathrm{Mg}_{2} \mathrm{Si}$ が犠牲 溶出したためと推定される。ただし, その後の腐食量増加 は抑制されており 10 年後で $5.6 \mathrm{~g} / \mathrm{m}^{2}$ の腐食量で, ALに対し て約3割減少，AZに対しては7割減少していた。以上のよ うに，長期間の大気環境下でも Mg 添加による耐食性向上 効果が確認された。

Fig.12に暴露材最表層の深さ方向の各元素プロファイル を示す。Uchida らの報告 ${ }^{17)} に$ にるようにALの表面には酸 化物に加えて S の濃化も認められた。一方, Al-8\% $\mathrm{Si}-6 \% \mathrm{Mg}$ めっき鋼板の表面の酸化膜厚みは, ALの約半分であり, 成 分としてはS に加えて $\mathrm{Mg}$ や Si 強度の増加も認められ, $\mathrm{Mg}$ や Siの濃化した腐食生成物による保護皮膜形成を示唆す る結果であった。

Fig.13に腐食部断面のEPMA分析結果を示す。ALは, Kawaguchi らの報告 ${ }^{18)}$ と同様にめっき層中の針状 $\mathrm{Si}$ 晶の近 傍の $\mathrm{Al}$ が優先溶解して針状 $\mathrm{Si}$ 晶に沿って合金層付近まで 腐食が進展していた。一方で, Al-8\% $\mathrm{Si}-6 \% \mathrm{Mg}$ めっき鋼板 は, 殆どの部位でめっき表面のみの腐食であった。めっき 表面にはGDSでの表面分析でも検出されたようにアルミ ニウム酸化膜中への Siの濃化が認められた。Pech-Canulら の報告 ${ }^{19)}$ にあるように, $\mathrm{Mg}_{2} \mathrm{Si}$ から溶出した $\mathrm{Si}$ がアルミニ ウムの腐食生成物中に混入にすることでアルミニウム酸化 膜が安定して防錆効果を発現したものと推定される。 $\mathrm{Mg}$ の濃化については特性 X線像からは不明瞭であった。検出 感度の影響と推定される。また，極一部で局部的なめっき 中の腐食が認められ，その腐食部位には $\mathrm{Al}, \mathrm{O}$, とともに $\mathrm{S}$ やSiが認められた。Siが濃化していることから，めっき中 に晶出した数 $\mu \mathrm{m}$ の塊状 $\mathrm{Mg}_{2} \mathrm{Si}$ が存在していた箇所と推定 

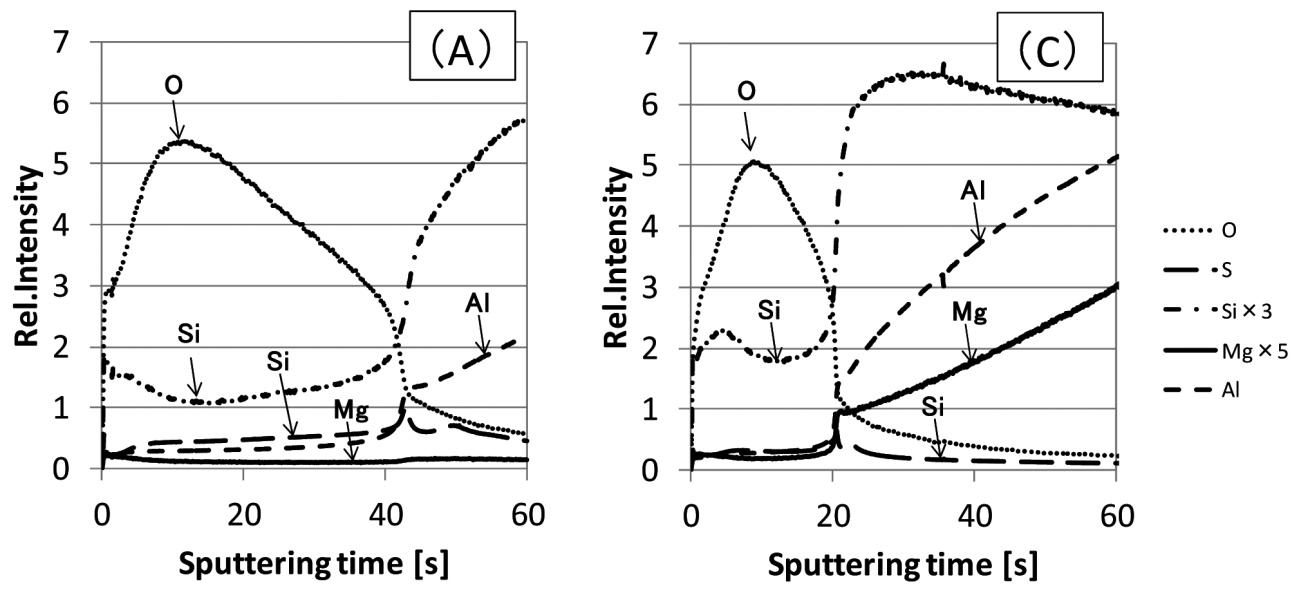

Fig. 12. GDS profiles of specimens exposed for 10 years (A) AL (C) Al- $8 \% \mathrm{Si}-6 \% \mathrm{Mg}$.
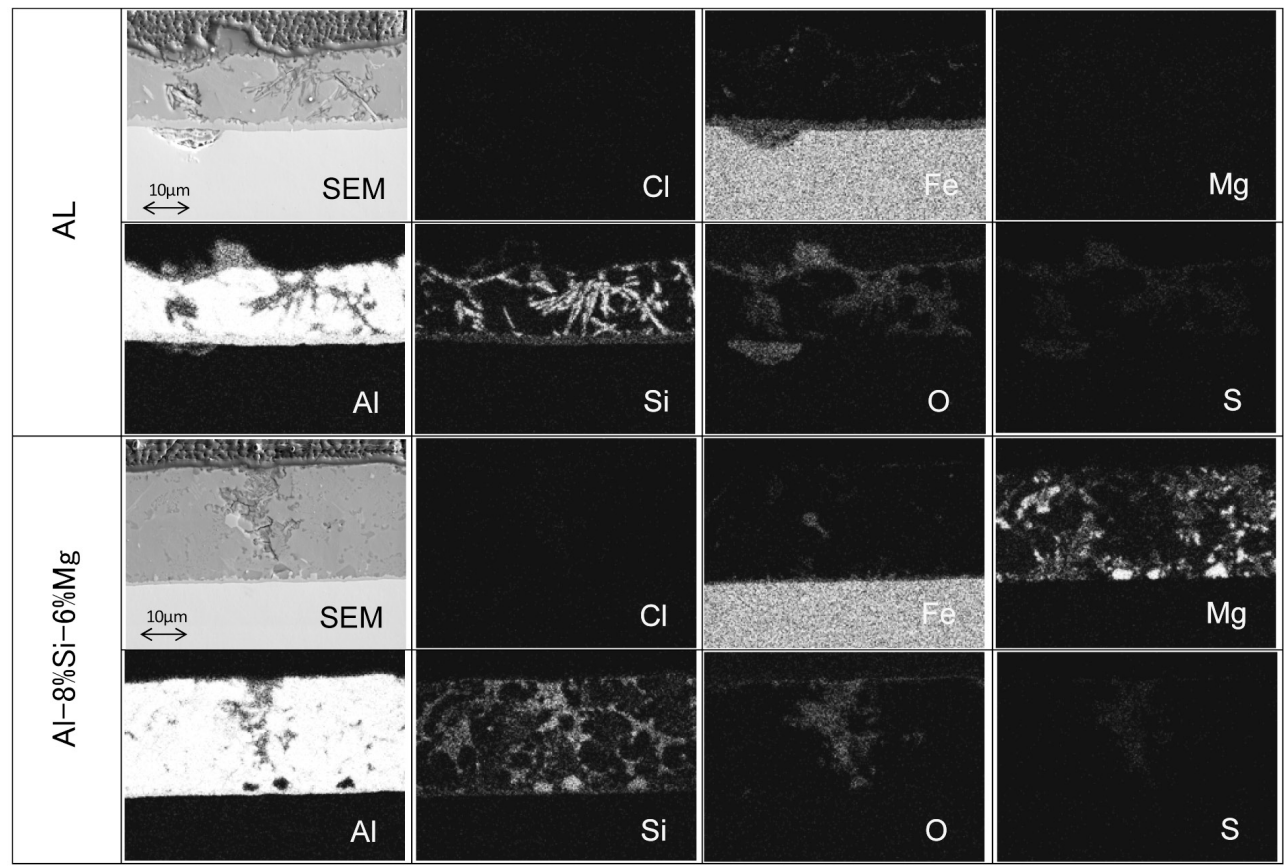

Fig. 13. Cross-sectional EPMA Image of specimens exposed for 10 years.

\section{される。}

Fig. 14 に 10 年暴露材を模擬雨水溶液中でカソード分極し た結果を示す。Al-8\% $\mathrm{Si}-6 \% \mathrm{Mg}$ めっき鋼板の溶存酸素の拡 散限界電流值は， $-0.56 \mathrm{~V}$ で $5.8 \times 10^{-8} \mathrm{~A} / \mathrm{cm}^{2}$ で $\mathrm{AL}$ の $1.0 \times$ $10^{-7} \mathrm{~A} / \mathrm{cm}^{2}$ に対して約 4 割低減しており，これらはめっき 表面に $\mathrm{Al}, \mathrm{O}, \mathrm{S}$ に加えて $\mathrm{Si}, \mathrm{Mg}$ が混入した腐食生成物に よる被覆効果と推察される。また, $\mathrm{Al}-8 \% \mathrm{Si}-6 \% \mathrm{Mg}$ めっき

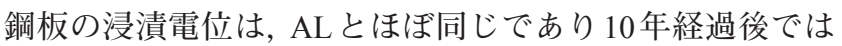
$\mathrm{Mg}$ 添加による犠牲防錆能は認められなかった。

以上のように, $\mathrm{Al}-8 \% \mathrm{Si}-6 \% \mathrm{Mg}$ めっ鋼板は大気環境下 で 10 年後でも優れた防錆能を示し，その理由として，Mg， $\mathrm{Si}$ 含んだ安定な $\mathrm{Al}$ の腐食生成物がめっき表面を被覆す ることで腐食因子である溶存酸素の拡散を抑制したことが 推定された。

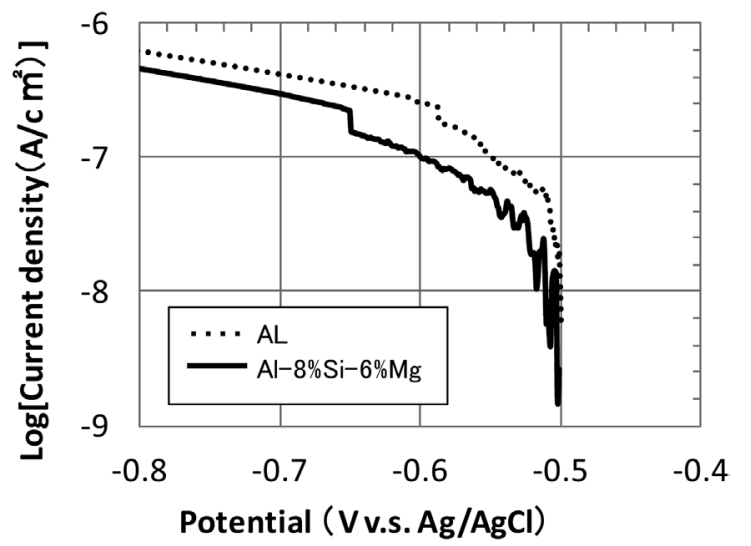

Fig. 14. Cathodic polarization curves of specimens exposed for 10 years in an artificial rain water at $25^{\circ} \mathrm{C}$. 


\section{4. 結言}

Al-Si-Mg系めっき鋼板の加工後耐食性に及ぼす組成の 影響を塩水噴霧試験にて検討し，さらに最も優れた耐食性 を示した $\mathrm{Al}-8 \% \mathrm{Si}-6 \% \mathrm{Mg}$ めっき鋼板の大気腐食環境下での 耐食性と形成する腐食生成物について調査した。得られた 結果は以下の通りである。

(1) Al-Si-Mg系めっき鋼板の塩水噴霧試験 500 時間での めっき腐食量は, 平板では各組成間でほとんど差異無く, $\mathrm{Al}-10 \% \mathrm{Si}$ めっき鋼板に比較して約 3 分の 1 であったのに対 して，加工材では各組成間で差異が生じ，Al-8\% $\mathrm{Si}-6 \% \mathrm{Mg}$ めっき鋼板が最も少なく, $\mathrm{Al}-10 \% \mathrm{Si}$ めっき鋼板の約 16 分 の 1 と優れた耐食性を示した。

(2) $\mathrm{Al}-8 \% \mathrm{Si}-6 \% \mathrm{Mg}$ めっき鋼板は，塊状 $\mathrm{Mg}_{2} \mathrm{Si}$ と $\mathrm{Al}$ 晶と $\mathrm{Al}-\mathrm{Mg}_{2} \mathrm{Si}$ 共晶組織で，針状の $\mathrm{Si}$ 晶はほとんど認められな かった。また，他の Al-Si-Mg系めっき鋼板より合金層が薄

く加工後のめっきや合金層の割れが最も少なかった。

（3） $5 \% \mathrm{NaCl}$ 水溶液中でのドロービード加工材の交流イ ンピーダンス法から求めた $\mathrm{Al}-8 \% \mathrm{Si}-6 \% \mathrm{Mg}$ めっき鋼板の反 応抵抗は, 初期は $\mathrm{Mg}_{2} \mathrm{Si}$ の活性溶解により低い值を示すも のの，経時とともに増加して 100 時間後にはAl-10\%Si めつ き鋼板より一桁高い值を示した。

（4）めっき層の一部を除去して鋼を露出させた部位は, 浸漬腐食試験後でも鋼の腐食が認められず，XPS 分析結果 より表面には $\mathrm{Mg}$ と $\mathrm{Si}$ を含有した $\mathrm{Al}$ 腐食生成物に覆われて いた。

(5) $\mathrm{Al}-8 \% \mathrm{Si}-6 \% \mathrm{Mg}$ めっき鋼板の屋外暴露試験 10年後で の腐食量は $5.6 \mathrm{~g} / \mathrm{m}^{2}$ で, ALより 3 割減少, AZより 7 割減少 しており，大気環境下でも良好な耐食性を示すことが確認 できた。

（6）10年の屋外暴露試験後のめつき表面には $\mathrm{Mg}, \mathrm{Si}, \mathrm{S}$ を含有した $\mathrm{Al}$ の腐食生成物が認められ，模擬雨水溶液中て
カソード電流值が ALに対して約 4 割減少していた。

以上のように, 合金層が薄いため加工時の合金層割れ比 率が少ない $\mathrm{Al}-8 \% \mathrm{Si}-6 \% \mathrm{Mg}$ めっ鋼板は, 塩害環境の塩水 噴霧試験とともに屋外暴露試験 10 年後でも AZP ALに対 して優れた耐食性を示すことが明らかとなった。

\section{文献}

1 ) S.Sudo: kougyou-zairyou, 45(1997), No.10, 94.

2 ) M.Suehiro, J.Maki, K.Kusumi, M.Oogami and T.Miyakoshi: Shinnittetsu Giho, 378(2003), 15.

3 ) K.G.Coburn: Metallurgia, (1961), No.7, 3.

4 ) S.G.Denner, R.D.Jones and R.J.Thomas: Iron Steel Int., (1975), No.6, 241.

5 ) O.Seri: J. Jpn. Inst. Light Met., 46(1996), No.8, 404.

$6)$ F.Kumon, H.Fukumoto and T.Deguchi: Nissin Steel Tech. Rep., 68(1993), 1.

7 ) F.Yoshizaki, Y.Hattori, Y.Miyoshi and A.Andou: Tetsu-to-Hagané, 89(2003), No.1, 180.

8 ) J.Maki, T.Omori, K.Asakawa, S.Higuchi and N.Okada: Shinnittetsu Giho, 361(1996), 52.

9 ) M.Enokida, E.M.Gamal A, A.Nishikata and T.Tsuru: CAMP-ISIJ, 23(2010), 361, CD-ROM.

10) D.Hanson and M.L.V.Gayler: J. Inst. Met., 26(1921), 321.

11) Binary Alloy Phase Diagrams, vol.1 ed. By T.B.Massalski, A. S. M., (1986), 129.

12) K.G.Coburn: Met. Eng. Q., Feb. (1964), 54.

13) P.T.Stroup and G.A.Purdy: Met. Prog., Jan. (1950), 57, 59.

14) Y.Morimoto, M.Kurosaki, K.Honda, K.Nishimura, S.Tanaka and A.Takahashi: Tetsu-to-Hagané, 89(2003), No.1, 161.

15) J.Maki, T.Izaki and K.Tano: J. Surface. Finish Soc. Jpn., 51(2000), No.12, 1229.

16) D.J.Willis: GALVATECH‘98, Sep., (1998), 337.

17) Y.Uchida, Y.Miyoshi and Y.Hirose: Nissin Steel Tech. Rep., 55(1987), 26.

18) H.Kawaguchi, Y.Miyoshi and T.Kittaka: Nissin Steel Tech. Rep., 78(1998), 52.

19) E.E.Coral-Escobar, M.A.Pech-Canul and M.I.Pech-Canul: J Solid State Electrochem, (2010)14, 803. 